\title{
THE COLLOCATION OF ENGLISH TEXTBOOK \\ FOR GRADE X IN SENIOR HIGH SCHOOL
}

\author{
*Sylvia Ulitha Prisscilia Hutapea \\ **Masitowarni Siregar \\ **Nora Ronita
}

\begin{abstract}
Hutapea, Sylvia Ulitha Prisscilia. Registration Number: 2133121060, The Collocation Of English Textbook For Grade X In Senior High School. A Thesis. English Literature Program, State University of Medan, 2018.

The aims of this study are to find out the types of collocation used in the English textbook for grade $\mathrm{X}$ students in senior high school, to find out the most dominant used of collocation, and to describe how the collocations applied in the 3 genre texts contained in the textbook. The data of this study were the collocations used in 3 genre texts, descriptive, recount, and narrative of an English textbook for tenth grade students in senior high school. After analysing the data, the researcher found 6 types of collocations used in the 3 genre text. The result showed that the textbook use 6 types of collocations (adjective + noun, verb + noun, noun + noun, verb + preposition, verb + adverb, adverb + adjective), and the most dominant collocation used was the adjective + noun type of collocation. The use of collocation in the narrative text was the biggest percentage of $(38 \%)$, followed by the recount text of (35\%) and the last was the descriptive text of $(27 \%)$.
\end{abstract}

Keywords: Collocation, Types of collocations, Genre Text, English Textbook.

\footnotetext{
*Graduate Status
}

**Lecturer Status 


\section{INTRODUCTION}

\section{Background of the Study}

Textbook has an important role in teaching and learning process. When the students failed to understand the content of text inside the textbook, the students will not get the knowledge of the textbook (Nenti, 2017). To help students understand the English language, the use of vocabulary in textbooks must be right. If it is appropriate, then the students should be able to interpret the exact words. In learning language, it requires a good understanding to interpret the meanings contained in a sentence. In this case the proper use of the word match becomes one of the things that need to be emphasized in interpreting the language (Yousefi, et.al:2012). As an international language, English has a large vocabulary which often confuses students in understanding the language. The size of vocabulary in English language is larger than Indonesian language. As a result, those who want to study or master English should be familiar with the thousands of vocabularies. Most English learners often ignore how important vocabulary is. They believe that grammar is more important than vocabulary. Meanwhile, learning vocabulary can be considered as a first step and an essential part to master a foreign language (Ghezelseflou \& Seyedrezaei, 2015).

To connect a word with another word it is needed to use collocation (O’Dell, 2008). For example, public goes with transportation, pay goes with attention, and stand with up. However 
many students do not understand and still ignore the use of collocation, whereas the using in the textbook is already correct. In fact, collocations have created confusion for Indonesian students because their meanings are not achieved through translation. It is obvious that many students love translating words from English into Indonesian. The results of translation are not satisfactory and even funny (Lubis, 2016). For example, take medicine means minum obat which translated into the English language directly will be drink medicine. Since this kind of collocation is not available in English collocation, so it is not acceptable. Another example is heavy smoker which in Indonesia means perokok berat. However, if heavy smoker translated literally or words by words, the definition will be berat perokok. These kinds of collocations confuse students since it does not have the same meaning as Indonesian collocation.

Collocation confuses the students in Indonesia because it does not have the same meaning as Indonesian collocation. To be familiar with that forms of collocations, students must read a lot. By analyzing the collocation that used in the English textbook, the student will understand the true meaning of the text in the textbook, so the students do not have any difficulty in interpreting them.

Roohani (2011), who investigated the extent to which lexical and grammatical collocations are used in high school and pre-university English textbooks, compared with the New Interchange book series. The results 
showed that the frequency and proportion of collocations in the high school and pre-university English textbooks were generally lower than those in the New Interchange book series.

Lubis (2013) analyzed the students' error in interpreting the collocations and find out the causes of the wrong collocations. He found four mistakes which is caused students could not understand the use collocation properly which are: students' lack of knowledge of collocation, differences of collocations between English and Bahasa Indonesia, students' low mastery of vocabulary, and strong interferences of the students' native language.

Based on the explanation above, this study tries to find out the use of collocation in English textbook for grade XI of senior high school .

\section{THE PROBLEMS OF STUDY}

Based on the background of study, the study formulated the problem as the following:

1. What were types of collocation used in English textbook for tenth grade students in Senior High School published by Bailmu?

2. What type of collocation was the most dominantly used in English textbook for tenth grade students in Senior High School published by Bailmu?

3. How were the collocation used in English textbook for tenth grade students in Senior High School published by Bailmu? 


\section{REVIEW OF LITERATURE}

The study was completed with theories correlated to the topic in order to enhance the knowledge toward the topic. The theories were consisted of definition of collocation and types of collocation.

Collocation means a natural combination of words; it refers to the way English words are closely associated with each other. For example, heavy rain, blond hair, and pay attention. (O'Dell:2008). Collocation aims to assist students in using the English language naturally. It also helps the students to increase the number of their vocabulary, especially for Indonesian students who learn English as their foreign language.

Collocation as language chunks which are memorized as whole units in order to achieve language fluency. It is a pair group of words that consists of two or more words and often used together written or spoken (Seretan 2011:9). Collocation is one of the concerns of lexicography which is lexical semantic. Lexicography is focus on the meaning and use of words, a central to dictionary making (Bieber 2000:21). Collocation can be defined as a term used to describe a group of words which occur repeatedly in a language. These kinds of co-occurrence can have a grammatical or lexical meaning (Carter 2012:62). Meanwhile, lexical semantic is the study of what individual lexical items mean. Why they mean, what they do, how one can represent all of this, and where the combined interpretation for an utterance comes. It is still defined as a tendency of a lexical item to co-occur with one 
or another words (Cruse, 1987). Raising the learners' understanding of the collocations of words is a matter of first rate importance (McCarthy 2008:21 in Lubis 2013: 18), since the task of learning collocations can present both intra-lingual and inter-lingual problems. Collocation as a term describing lexical relations is not well-defined, and unfortunately joining words that are in principle semantically compatible does not always produce acceptable collocations, for example strong tea is an acceptable collocation in English but powerful tea is not, in the same way that many thanks is well-formed but several thanks is not.

1. McCarthy and O'dell (2008:12) divided different types of collocation into 6 types. There are:

a. Adjectives + Nouns

Example: Caroline wears some bright color for her clothes in daily.

b. Verbs + Nouns

Example: Every day, I take a shower at 6 o'clock.

c. Noun + Noun

Example: Would you like to have a cup of coffee?

d. Verbs + expression of prepositions.

Example: At first her eyes filled with horror, and then she burst into tears. 
e. Verbs + adverbs

Example: Daddy smiled proudly as he looked at the photos of his daughter graduation.

f. Adverbs + Adjectives

Example: Sysil is a highly successful businesswoman.

\section{RESEARCH METHODOLOGY}

\section{Methodology}

This research used the descriptive qualitative method to describe or explain the study.

The data of this study were the collocations used in 3 genre texts. There were 3 texts of descriptive text, 3 texts of recount text, and 3 texts of narrative text, which were taken from the English textbook for tenth grade students in senior high school, entitled 'Let's Learn English', written and published by Bailmu in 2016.

In order to collect the data, this study used some steps. First, the researcher read the texts contained in the textbook. Second, the researcher selected the reading texts contained in the textbook. Third, the researcher selected the phrases contained in the text. The last step, the researcher coded the reading texts in the textbook.

Then, the data was analyzed by using descriptive qualitative method in which the steps that were done, they were; identifying, 
classifying, abstracting, and making the conclusion from the analysis that had been conducted.

\section{DATA ANALYSIS AND RESEARCH FINDINGS}

\section{Data Analysis}

After collecting and analysing the data, it was found that there were 6 types of collocation used in Let's Learn English textbook for grade X students of Senior High School published by Bailmu in 2016 were further analyzed based on the types of collocation according to the theory of McCarthy and O'dell (2008). The collocation was distinguished into 6 types, which are Adjectives + Nouns, Verbs + Nouns, Noun + Noun, Verbs + Expression of prepositions, Verbs + Adverbs, and Adverbs + Adjectives.

\section{Analysis of types of collocation used in the textbook}

Based on the theory of McCarty and O'Dell (2008) there was 6 types of collocation, which were adjective + noun, verb + noun, noun + noun, $v e r b+a d v e r b, v e r b+$ preposition, and adverb + adjective. All 6 types of collocation were found in Let's Learn English textbook for tenth grade students of Senior High School published by Bailmu. The collocations took from 3 genre texts in Let's Learn English Textbook for tenth grade students in Senior High School published by Bilmu, where descriptive text use 5 types of collocation except verbs + adverbs, narrative text use 
5 types except noun + noun, and recount text use whole 6 types of collocation.

\section{The finding of most dominant type of collocation used in the textbook}

Based on the data result could be concluded that the total number of collocations that used in Let's Learn English Textbook for tenth grade students in Senior High School published by Bilmu were 134 collocations, with adjectives + nouns as much as 43 collocations, verbs + nouns as much as 40 collocations, noun + noun as much as 7 collocations, verbs + prepositions as much as 10 collocations, verbs + adverbs as much as 12, and adverbs + adjectives as much as 21 collocations. The collocations took from 3 genre texts in Let's Learn English Textbook for tenth grade students in Senior High School published by Bilmu, where descriptive text consisted of 5 types of collocation except verbs + adverbs, narrative text also consisted of 5 types except noun + noun, and recount text consisted of whole 6 types of collocation. It concluded that those 3 genres texts in the textbook almost use whole 6 types of collocations.

From the chart above could be concluded that the most dominant type of collocation used in Let's Learn English Textbook for tenth grade students in Senior High School published by Bailmu was 
adjective + noun as much as 43 collocations that found in those 3 genre text; descriptive, recount, and narrative text.

\section{The analysis of how the collocations used in the textbook}

The study of collocation used to create a clear collocation in the literal text (Firth, 1957). This makes the use of collocation in the text very essential and has considerable variation in its use. Because of the different variations, the use of the collocation of each text is not same and has its own characteristics. How the use of collocations in the texts contained in Let's Learn English Textbook for grade ten students in Senior High School published by Bailmu are described below.

\section{a. Descriptive Text}

This textbook contained of 10 descriptive texts. But it only took 3 texts as a represented from this genre. From 6 types of collocations, this genre text used 5 types of collocation. There were 36 collocations that could be found in this genre text. The types of collocation used in descriptive text were shown in table below.

Table 4.8 The types of collocation that used in Descriptive Text

\begin{tabular}{|lcc|}
\hline No & Types of Collocation & Frequency \\
\hline $\mathbf{1}$ & Adjective + Noun & 20 collocations \\
\hline $\mathbf{2}$ & Verb + Noun & 9 collocations \\
\hline $\mathbf{3}$ & Noun + Noun & 5 collocations \\
\hline $\mathbf{4}$ & Verb + Preposition & 2 collocations \\
\hline $\mathbf{5}$ & Adverb + Adjective & 1 collocation \\
\hline & TOTAL & $\mathbf{3 6}$ collocations \\
\hline
\end{tabular}


Based on the table could be concluded that descriptive text use adjective + noun collocation a lot. One of the data results of adjective + noun collocation was 'green lake', where green as an adjective that described what a lake looks like, where lake was a noun. More than half of collocations contained in 3 descriptive texts using a combination of adjective + noun, because the purpose of descriptive text is to describe and reveal a particular person, thing, and place (Pardiyono : 2007). It proves how important the use of collocation in this genre text, especially the type of adjective + noun collocation.

\section{b. Recount Text}

Department for Educational and Child Development (2012) divided recount text into 4 types. There are personal recount, factual recount, imagination recount, and procedural recount. This English textbook consisted of 10 recount text, 8 texts were personal recount and 2 texts were factual recount. 3 texts as a represented from this genre were personal recount, which is personal recount is retelling experiences or events that happened in the writer own life. The writer must structure the story in a way that makes sense while using language that matches the same purpose. Recount text use whole 6 types of collocation. There were 46 collocations that could be found in this genre text. The types of collocation used in recount text were shown in table below. 
Table 4.8 The types of collocation that Used in Recount Text

\begin{tabular}{|lcc|}
\hline No & Types of Collocation & Frequency \\
\hline $\mathbf{1}$ & Adjective + Noun & 18 collocations \\
\hline $\mathbf{2}$ & Verb + Noun & 17 collocations \\
\hline $\mathbf{3}$ & Noun + Noun & 2 collocations \\
\hline $\mathbf{4}$ & Verb + Preposition & 1 collocation \\
\hline $\mathbf{5}$ & Verb + Adverb & 3 collocations \\
\hline $\mathbf{6}$ & Adverb + Adjective & 5 collocations \\
\hline & TOTAL & $\mathbf{4 6}$ collocations \\
\hline
\end{tabular}

From the total number of collocation could be concluded that adjective + noun was the most type of collocation used in this genre text. It described that the use of adjective + noun type of collocation were essentially needed, specifically for personal recount text.

\section{c. Narrative Text}

Another type of text contained in Let's Learn English Textbook for tenth grade students of Senior High School was the narrative text. This textbook consisted of 13 narrative texts. But it only took 3 texts as a represented from this genre. From 6 types of collocations, this genre used 5 types of collocation. This narrative text was the most dominant text use collocation. It was found that this type of text has 51 collocations. The types of collocation used in narrative text were shown in table below.

Table 4.8 The types of collocation that Used in Narrative Text 


\begin{tabular}{|lcc|}
\hline No & Types of Collocation & Frequency \\
\hline $\mathbf{1}$ & Adjective + Noun & 5 collocations \\
\hline $\mathbf{2}$ & Verb + Noun & 14 collocations \\
\hline $\mathbf{3}$ & Verb + Adverb & 9 collocations \\
\hline $\mathbf{4}$ & Verb + Preposition & 7 collocations \\
\hline $\mathbf{5}$ & Adverb + Adjective & 15 collocations \\
\hline & TOTAL & $\mathbf{5 1}$ collocations \\
\hline
\end{tabular}

Based on 3 narrative texts that have been analyzed could be found that adverb + adjective was the most dominant collocation used in this genre. It was different with another genre text, which were recount and descriptive text mostly use adjective + noun collocation.

The basic purpose of narrative is to entertain, to gain and to hold a readers' interest. However, narratives can also be written to teach or inform, to change attitude or social opinion. Narratives sequence people or characters in time and place but differ from recounts in that through the sequencing, the stories set up one or more problems, which must eventually find a way to be resolved. This made the adverb + adjective collocation as an important element in the word combination within the narrative text type. 


\section{CONCLUSION}

After analyzing the data, the conclusions drawn presented as follows:

1. The types of collocation used in the three genre texts (descriptive, recount, and narrative) contained in the Let's Learn English Textbook for grade X students in Senior High School published by Bailmu were adjective + noun, verb + noun, noun + noun, verb + adverb, verb + preposition, and adverb + adjective. Descriptive text consist of 5 types of collocation except the verbs + adverbs collocation, narrative text consist of 5 types of collocation except the bnoun + noun collocation, and recount text consist of whole 6 types of collocation.

2. The most dominant type of collocation used in the Let's Learn English Textbook for grade X students in Senior High School published by Bailmu was the adjective + noun collocation as much as 43 collocations.

3. In using the collocations, there were some differences found in each type of text contained in Let's Learn English textbook. The narrative text was the genre of text that mostly used collocation with 51 collocations, the adverb + adjective collocation was the larger used within. Then followed by the recount text with 46 collocations, the adjective + noun colocations was the most dominant found in this genre of text. And the last was descriptive text with 36 collocations, same like recount text this genre text used mostly adjective + noun collocation. 


\section{REFERENCES}

Alfahadi, et al. 2014. Promoting Awareness of Teaching Collocations Techniques to Beginers (Adjective - Noun Collocations). European Scientific Journal, Vol. 10 No. 10, April 2014.

Carter, R. 2012. Routledge Linguistics Classics : Vocabulary Applied

Ghezelseflou, M., \& Seyed, S. 2015. The Effect of Teaching Vocabulary Learning of Iranian EFL Students. Journal of Language Sciences and Linguistics, Vol. 3 No. 1 pp. 9-16. (retrieved from http://www.jlsjournal.com).

Lubis, C. 2016. A Discourse Analysis of Collocation in English Textbook for Grade X in Senior High School. Thesis. UNIMED. Medan

Lubis, S. 2013. Collocation as Source of Translation Unacceptability Indonesian Students' Experiences. International Journal of English Linguistics, Vol. 3 No. 5, September 2013.

O'dell, F., \& Michael, M. 2008. English Collocation in Used English Advanced. Cambridge : Cambridge University Press.

Roohani, A. 2011. Collocations in High School and Pre-University English Textbooks Versus New Interchange Book Series. The Journal of Asia TEFL, Vol. 8 No. 3.

Seretan , V. 2011. Syntax-Based Collocation Extraction (Text, Speech and Language Technology Series Vol. 44), Dordect : Springer. 